Available at: http://news.eizvestia.com/news_politics/full/417-v-luganskoj-oblasti-mitinguyushhie-pereputali-flagi-rossii-i-francii (Accessed: 12.11.2017).

14. "Indigenous separatists" do not know how the word "Donbass" is written. Internet publication "Our Niva". 08.04.2014. Available at: https://nn.by/?c=ar\&i=126268\&lang=ru (Accessed: 10.11.2017)

15. Popravko Oleg "Another day in the DNR." Internet-publication of Rufubula. 05.2014. Available at: https://rufabula.com/author/ oleg_popravko/1446 (Accessed: 10.09.2017)

16. A video story about breaking and burning the flag of FC Shakhtar, which was confused with the flag of the "Right sector". 10.03.2014. Available at: https://www.youtube.com/watch?v=dA3iWxtlYu0 (Accessed: 14.12.2017)

17. Massing the Kremlin: different people around Putin are surrounded by the same people. Journalistic Investigation Lyudmila Balabay. Internet source "Voice of Russian-speaking America". 08.01.2017. Available at: http://www.forumdaily.com/massovkakremlya-na-raznyx-foto-putina-okruzhayut-odni-i-te-zhe-lyudi/ (Accessed: 08.06.2017)

18. Putin took part in baptismal bathing on Lake Seliger - Russia-24. 19.01.2018. Available at: https://www.youtube.com/ watch?v=wQSGqh6pwmc (Accessed: 02.02.2018)

19. Putin turned out to be a Catholic: He is baptized as a Catholic in the ice-hole. Analiz of Golden Tengu TV. Available at: https:// www.youtube.com/watch?v=ONwEAA9zNdA (Accessed: 02.02.2018)

20. Russia has used footage from the computer game as evidence of US assistance to IGIL. Katerina Moskalets. Internetpublication Usa.one. 15.11.2017. Available at: https://usa.one/2017/11/rossiya-ispolzovala-kadry-iz-kompyuternoj-igry-kak-dokazatelstvopomoshhi-ssha-dlya-igil/ (Accessed: 19.12.2017)

21. Moskalets Katerina. In Russia, again showed the footage of a video game instead of a photo from Syria. The Internet-visa Usa.one. 02.26.2018. Available at: https://usa.one/2018/02/v-rossii-snova-pokazali-kadry-videoigry-vmesto-foto-iz-sirii/ (Accessed: 27.02.2018)

(c) Стругацький Василь

Надійшла до редакції 27.02.2018

\title{
ХОДАНИЧ ЮРІЙ,
}

викладач кафедри філософії,

Ужгородський національний університет, м. Ужгород

\section{ПОРІВНЯЛЬНИЙ ІДЕЙНО-КОНЦЕПТОЛОГІЧНИЙ АНАЛІЗ СОЦІАЛЬНО-ФІЛОСОФСЬКОГО ПІДХОДУ ДО СУСПІЛЬНИХ АСПЕКТІВ МИЛОСЕРДЯ}

Стаття присвячена порівняльному ідейно-концептологічному аналізу соціально-філософського підходу до суспільних аспектів милосердя. Феномен милосердя досліджується автором крізь призму різноманітних західних соціально-етичних учень (еволюціонізм, утилітаризм, гедонізм, лібералізм, неомарксизм та постмарксизм). У розрізі еволюціонізму милосердя набуває значення альтруїзму. Окрема увага приділяється концепції взаємодопомоги П. Кропоткіна. В утилітаризмі милосердя розглядається крізь призму індивідуальної та суспільної користі. У свою чергу, у контексті лібералізму милосердя втрачає свою суспільну цінність, адже в центрі уваги постає вільна особистість 3 її власним моральним вибором. Автор аналізує окремим чином концепцію розумного егоїзму А. Ренд. Крізь призму суспільно-прикладних досліджень неомарксизму та постмарксизму милосердя постає фактором активності суб'єкта щодо оточуючого його середовища та подальшого впливу на розвиток суспільства.

Ключові слова: милосердя; еволюціонізм; прагматизм; утилітаризм; закон взаємної допомоги; лібералізм.

Постановка проблеми. На сучасному етапі розвитку в силу глобалізаційних процесів, ускладнення різних сорер життєдіяльності суспільства відбувається значне утвердження індивідуалізму в суспільному бутті та свідомості, усе більшого поширення набуває соціальне відчуження людини. У зв'язку із цим постає проблема по- шуків альтернативних шляхів розвитку суспільства в бік посилення соціальної взаємодії, активної співпраці між людьми в напрямку позитивної трансформації суспільного розвитку. Одним із таких шляхів чи факторів, на наше переконання, постає милосердя. Як феномен милосердя досліджувалось у різних його інтерпретаці- 
ях ще 3 давніх часів, однак найбільшого поширення отримало в рамках світоглядних та концептологічних орієнтацій західної соціально-філософської думки. Аналіз таких підходів надалі надасть змогу краще зрозуміти шляхи впровадження милосердя в суспільну практику задля здійснення суспільних перетворень.

Стан вивчення проблеми. Соціально-філософський підхід до дослідження милосердя використовували в своїх роботах Р. Апресян, М. Бердяєв, Є. Березіна, В. Биков, Є. Борзова, Б. Вишеславцев, П. Гайденко, А. Гусейнов, Д. Датта, П. Кропоткін, П. Поломошнов, А. Ренд, В. Соловйов, Г. Спенсер, В. Старостін, В. Унрау, А. Шопенгауер. На дисертаційному рівні дослідження милосердя прямо чи дотично здійснено В. Васильєвим ("Проблематика ціннісних орієнтацій в компаративістиці Росії, Сходу та Заходу" (2006)), Р. Дружиніним ("Репрезентації милосердя в сучасній культурі" (2013)), Є. Логуновою ("Феномен милосердя: досвід соціально-філософського аналізу" (2012)), Л. Швачкіною ("Гуманність в контексті культурних традицій Сходу та Заходу" (2011)). Проте до цього в літературі не проводився саме порівняльний ідейно-концептологічний аналіз соціальнофілософського підходу до суспільних аспектів милосердя крізь призму західної філософської думки.

У сучасній західній рефлексії проблема милосердя досліджується в контексті визначення того, наскільки останнє може бути "справедливим" та як воно поєднується з системою юстиції, кримінальних покарань тощо (К. Беннет "Межі милосердя" (2004) [1] та монографія Л. С. Мейєр "Справедливість милосердя" (2010)) [2]. У монографії Дж. Мерфі та Ж. Гемптона "Прощення і милосердя" (1988) аналізується проблема того, яким чином співвідносяться феномени прощення та милосердя з приписами закону [3]. К. Кессерлінг у монографії "Милосердя та авторитет у державі Тюдорів" (2003) ставить милосердя на "ваги" здійснення помилування сувереном [4]. У такий спосіб можна обґрунтовувати думку про те, що сучасні західні дослідження феномену милосердя торкаються його реалізації в контексті права та політики.

Метою дослідження $€$ проведення порівняльного ідейно-концептологічного аналізу соціально-філософського підходу до суспільних аспектів милосердя.

Виклад основного матеріалу. Варто вказати, що західна філософсько-наукова традиція розробила значну кількість підходів до розуміння сутності, проявів милосердя як феномену. Останні можливо розглядати в контексті, зокрема, соціально-етичних учень (еволюціоністський, утилітарний, ліберальний тощо).

Еволюціоністська етика (Ч. Дарвін, Г. Спенсер, В. Ефроїмсон) виходить із розуміння моралі як такої, що має природне походження, в їі основі - виживання роду чи племені, а для цього - необхідність співпраці та взаємодопомоги. В основі "моральної" поведінки живих істот лежать соціальні інстинкти, які задовольняються в спільноті собі подібних. Завдяки високому розвитку душевних здатностей такі соціальні інстинкти перетворюються на моральні настанови. Окрім цього, щодо людського суспільства важливу роль у моральній поведінці відіграють симпатія, мова та звичка [5, с. 35-36]. Таким чином, згідно з позицією Ч. Дарвіна, природа сама закладає основи морального співжиття.

Милосердя в розрізі еволюціоністської етики розглядається крізь призму альтруїзму. Тут альтруїзм постає як "індивідуальна поведінка, яка збільшує можливості пристосування та розмноження групи родичів, при тому, що відповідні шанси індивіда можуть зменшитися" [5, с. 39].
Г. Спенсер виділив два види альтруїзму - справедливість (необхідна для підтримання суспільної рівноваги, а тому є справою суспільною) та благодійність (як приватна справа). При цьому держава не може приписувати благодійність. Зокрема, благодійність не може бути примусовою, коли держава встановлює обов'язковий податок на допомогу бідних. У свою чергу, благодійність теж має два види: негативна (передбачає утримання від діяльності в тих випадках, коли вона могла б привести до досягнення егоїстичних задоволень) та позитивна (жертвування чимось, що може принести користь іншим) [6, с. 495-496].

Інший представник еволюціоністської етики В. П. Ефроїмсон переконаний, що саме закон природного відбору "породив і закріпив інстинкти та емоції найбільшої моральної сили", а почуття обов'язку породжене не божественним законом у серці, а "виробленим за десятки тисяч поколінь еволюції комплексом психічних, поведінкових реакцій, настільки ж необхідних людству, як і мова і як уміння користуватися знаряддями". Почуття альтруїзму передбачає взаємність, інакше альтруїст зазнає постійної експлуатації, тим самим утверджуючи егоїзм експлуататора. У зв'язку із цим указується, що альтруїзм необхідним чином пов'язується 3 почуттям справедливості, що "повинно не лише переривати прояв альтруїзму щодо невдячного, але й загрожувати йому серйозною бідою" [7, с. 54-56].

Розмірковуючи над еволюційним підходом до феномену милосердя Е. Г. Логунова [8] указує на декілька аспектів. Перший базується на тому, що милосердя постає способом захисту та збереження потомства. Передбачається, що людські гени схиляють нас до турботи про тих, хто, як і ми, є їх носіями. Другий аспект передбачає розгляд милосердя в контексті вибору статевого партнера відповідно до певних характеристик. Звідси милосердя пов'язується зі здатністю відчувати емоції та діяти безкорисливо. Третій аспект розглядає схильність до милосердя як одного з критеріїв формування спільних відносин із незнайомими людьми [8, c. 22].

Близькою за змістом до феномену милосердя $є$ ідея взаємної допомоги серед тварин та людей як рушія прогресу, яку висунув П. Кропоткін. Основи такої взаємної допомоги філософ бере з тваринного світу, використовуючи, таким чином, еволюційний підхід. Наголошується, що поряд із природним законом боротьби за виживання має місце закон взаємної допомоги, що є більш важливим з точки зору прогресивного розвитку тваринного світу та суспільства. І йдеться не стільки про любов та симпатію між видами, скільки про певний інстинкт вселюдської солідарності чи "інстинкт товариськості", взаємзалежності між людьми. Саме це, а не любов чи симпатія, на переконання П. Кропоткіна, лежить в основі прогресивного розвитку моральних почуттів [9].

Певним чином у структурі "закону взаємної допомоги" можна говорити й про милосердя, яке неможливе без турботи про живе, бажання допомоги, добра, а загалом блага для інших. Усе ж взаємна допомога та милосердя знаходяться на дещо різних рівнях. Якщо перша слугує засобом до виживання за складних природних та суспільних умов життя, а звідси через сприяння колективному забезпечується індивідуальне, то друге $\epsilon$ чеснотою, що переважно має місце вже в суспільному розвитку, базується на співчутті, жертовності, любові до ближнього та всього живого. Саме ж милосердя П. Кропоткін виводить із вселюдського закону вза- 
ємної допомоги. Завдяки християнській церкві взаємна допомога перетворилась на милосердя як "чесноту, що надихається звище"; воно розглядається як перевага того, хто дає, над тим, хто отримує. На цій основі, указує фрілософ, було сформовано велику кількість релігійних благодійних фондів [9].

У свою чергу, соціально-моральний підхід до природи милосердя, на відміну від еволюційного, постає як центральний атрибут гуманного суспільства, воно, як указує Е. Г. Логунова, "пробуджує в людях співчуття та формує між ними зв'язки, що базуються на безкорисливій взаємодопомозі" [8, с. 22]. Відповідно до цієї концепції милосердя виникає на ранніх стадіях формування людських суспільств із почуття взаємодопомоги. Тобто милосердя постає тут як атрибут винятково людського співтовариства. На думку Р. Г. Апресяна, "альтруїстичним, моральним робить не визначена за своїм малюнком дія, але головним чином те, на які імперативно-ціннісні стандарти опирається людина, як вона ставиться до своїх дій". Звідси моральний вибір є "персональний, принциповий, духовний", він "втілюється у діянні, зорієнтованому на повинне" [5, с. 58].

Ми переконані, що про милосердя як феномен у його сутнісному значенні може йти мова лише в контексті соціально-морального підходу, а саме: як моральної ціннісної установки індивідів у суспільстві. У рамках же еволюційного підходу йдеться не про феномен милосердя як такий, але про окремі його передумови, такі як альтруїзм, принцип взаємодопомоги тощо.

Західна традиція також сформувала розуміння гедоністичної етики, в основі якої лежить принцип задоволення, що виступає джерелом та метою моральної поведінки. Відповідно, при зустрічі людини зі стражданням єдиним виходом є його уникнення чи відкидання. Гедонізм постає як постійне й необмежене прагнення до задоволень різного характеру, це тактика егоїзму, що замкнутий на собі. Ми впевнені, що на цій установці суспільство не могло б функціонувати як єдине ціле. Відповідно, ставити милосердя "на терези" гедоністичної етики не має підстав.

Значною мірою сучасна практика милосердя, що реалізовується в суспільстві, базується на принципах утилітаристської етики. Засновники утилітарної етики І. Бентам та Дж. С. Мілль кінцевою метою дій людини та єдиним змістом поняття морального блага називають задоволення. Для цього використовують категорію "щастя". При цьому вищим критерієм моральності постає принцип користі, "який полягає в прагненні до досягнення найбільшого щастя для найбільшої кількості людей". Саме мотив симпатії, а також мотив любові до дружби та любові до репутації, за І. Бентамом, схиляють людину, яка переслідує власні інтереси, до врахування щастя інших $[10$, с. 21-22]. Зокрема, це може стосуватися благодійності.

За Дж. С. Міллем, вищою формою реалізації утилітаристських цінностей $є$ самопожертва, яка, однак, спрямована на суспільно корисні наслідки. Мислитель виходить з рівнозначності власного щастя та щастя інших, об'єктивні рамки яких формуються законами, освітою та суспільною думкою. При цьому, з точки зору моралі, суспільний вимір учинків важливіший, аніж індивідуальний [10, с. 25-26]. Те, що спрямовується на благо суспільного, але на основі раціонального усвідомлення індивідом, $є$ етичним в утилітаризмі.

Дж. С. Мілль виділяє дії по справедливості та дії з доброзичливості. Якщо перші (відмова від вчинення таких дій, що порушують законні інтереси інших осіб) $€$ обов'язковими для кожного, то другі (наприклад, благодійність) здійснюються за доброю волею індивіда. Звідси турбота про благо суспільства може обмежуватися тільки незаподіюванням шкоди інтересам інших членів суспільства [11, с. 101].

Утилітаристи вважають, що об'єктивним критерієм морального вчинку постає користь, що дозволяє забезпечити максимальне щастя для найбільшої кількості людей. Користь дозволяє "уникнути суто егоїстичного розуміння щастя: той, чия діяльність приносить користь, сприяє не лише своєму, але й загальному щастю" [12, с. 89]. У якості життєвого принципу користь виражена в максимі: "Виходячи з власного інтересу, витягуй з усього користь". Крім цього, важливими ціннісними орієнтирами утилітаризму постають успіх, ефективність та вигода [5, с. 198-199]. Сучасна суспільна практика милосердя, зокрема виражена в благодійній, волонтерській діяльності, будується саме на принципі поєднання індивідуальної та суспільної користі. Відповідно, говорити про повну безкорисливість дій не доводиться.

Р. Г. Апресян в основу моральної поведінки, з точки зору утилітаризму, ставить розуміння реальності, тобто перебування у сфері сущого (постановка цілей, розрахунок можливостей, передбачення результатів, урахування досвіду та ситуації в суспільстві). Натомість, утилітаризм ігнорує сферу повинного (ідеалу) [Там само, с. 201-202]. Моральні цінності "можуть приноситися прагматиком у жертву своїм практичним цілям, розглядатися ним лише як засоби" для досягнення власних інтересів [Там само, с. 224].

В основі відносин корисності лежить приватний інтерес, але який водночас $€$ також соціально визначеним. Моральні мотиви в етиці користі "виявляються адаптованими до "повсякденної" соціальної практики, за допомогою якої моральний ідеал перекладається, наскільки це можливо, на мову суспільних відносин". Принцип користі, вважає Р. Г. Апресян, стає однією з ідейних передумов громадянського суспільства (в основі якого - принцип суспільної корисності), інакше останнє постає "сорерою егоїзму та взаємної ворожості" [5, с. 229230]. Принцип взаємної користі (у рамках суспільства) передбачає своєрідний обмін засобами для задоволення людьми своїх інтересів. Проте, переконаний російський фрілософ, відносини взаємної користі мають речовий характер, адже роблять із людей лише "носіїв товарів і послуг, виконавців певних ролей та функцій", унаслідок чого людина не бачиться особистістю. У такий спосіб людські відносини позбавляються людськості, а, відповідно, ціннісного підґрунтя [Там само, с. 232]. Звідси можливо простежити відмінність у розумінні милосердя з точки зору утилітаристської етики та етики в її християнському смислі. Якщо перша неможлива без урахування особистої користі для благодійника, базується на розрахункові, прогнозуванні, то християнська етика передбачає жертовність людини, що виявляє милосердя, її альтруїстичну спрямованість на іншого, будується на служінні.

Утилітаристська етика значною мірою пов'язана 3 прагматистською. С. Л. Бурмістров указує, що ядром антропології прагматизму є теза про людину як істоту діяльнісну (діючу), у центрі якої - система їі інтересів, а тому людина завжди в різний спосіб переслідує власні інтереси. Самі ці (приватні) інтереси й визначають поведінку, характер, інтелект, соціальне становище, культурні установки людини. Мораль звідси стає "вільною від жорстких правил та пов'язаною скоріше ситуаціями 
й цілями" [13, с. 114-115]. Оптимальним способом поведінки, за В. Джеймсом, $є$ "прагматистська максима" така, що формується зі зручностей контактуючих сторін, максимальна сума задоволення потреб. У свою чергу, своєрідним перетворенням моралі на "моральну інженерію" (інструментальну чи цілком ситуативну мораль) постає етична концепція американського фрілософра прагматизму Дж. Дьюї. 3 його точки зору, мораль не $\epsilon$ певним "набором правил чи дій", натомість кожна ситуація унікальна, а благо, що їй відповідає, слід виявити, спроектувати та досягти. Відповідно, має місце переконання, що розум "повинен розробити методи, за допомогою яких можна було б детально аналізувати потреби, умови, труднощі, ресурси конкретних ситуацій", а також слід розробляти "розумні плани дій, спрямовані на покращення цих ситуацій" [14, с. 175-176]. Такий підхід цілком відображає діяльність сучасних благодійних організацій та фондів.

Синтезом традиціоналістської та утилітаристської етики О. М. Яркова називає етику лібералізму, що має у своїй основі принцип самоорганізації як "принцип покладання цінностей на основі раціонального аналізу та синтезу різних елементів дійсності" [Там само, с. 160]. Етика лібералізму ґрунтується на декількох положеннях: вищою цінністю визнається свобода індивіда в різних сферах індивідуального та суспільного буття; серед визначальних економічних механізмів суспільства - капіталістичне виробництво, вільний ринок, свобода конкуренції, приватна власність; серед політико-правових механізмів - демократія та права людини. Тут слід додати, що свобода в лібералізмі, по суті, не може бути обмеженою (хіба що свободою іншого індивіда). Звідси лібералізм "звільняє" індивіда від культури, моральності, ціннісних орієнтацій через те, що прагне до вигоди в суспільному (загальному) її масштабі [15, с. 167-168]. У такий спосіб лібералізм утверджує індивідуалізм у суспільстві. Відповідно, інтереси індивіда стають вищими за інтереси суспільства.

Ліберальна етика максимально віддаляє індивіда від суспільної моралі, роблячи останнього власним "законодавцем" у питанні добро-зло щодо самого себе. Мораль визначається як "особиста справа індивіда". У такий спосіб мораль у ліберальній етиці стає "товаром", однією з ринкових пропозицій [16, с. 36].

На думку А. А. Денисова, єдиним реальним моральним механізмом, що дозволяє "гармонізувати" приватні та суспільні інтереси, з точки зору ліберальної етики, $\epsilon$ конформізм. Він дозволяє підтримати певну стабільність у суспільстві, однак така єдність матиме винятково механічний характер, що позбавлений живих людських зв'язків. Конформізм, отже, "знищує особовий, споріднений характер відносин між людьми, поглиблює взаємну відчуженість" [Там само, с. 38]. Так індивідуальний егоїзм перетворюється на колективний.

М. Віссенбург указує на суттєву відмінність між класичним та соціальним лібералізмом. Перший, на його думку, передбачає, що держава існує лише для захисту прав індивіда на життя, власність та особисту безпеку від посягань на них інших, тоді як соціальний лібералізм очікує від держави активного сприяння індивідуальній автономії, завдяки чому допустиме певне обмеження у свободі індивідів, а держава має право обмежувати небажаний стиль життя чи, навпаки, заохочувати бажаний [17, с. 89-90]. Зокрема, можна додати, що саме в контексті соціального лібералізму функціонує сучасна благодійність, адже її значною мірою заохочує держава як суспільно корисну, хоча й за добровільним вибором кожного.
Яскравим представником ліберальної етики можна назвати А. Ренд (концепція розумного егоїзму). Сутністю морального існування американська письменниця та філософ називає "турботу про власні інтереси". Вищий пункт моралі - "індивід, його виживання та добробут" [15, с. 171-172]. У такий спосіб мораль визначається винятково крізь призму егоїстичних інтересів індивіда, забезпеченню яких повинна слугувати. Критерієм цінності етики А. Ренд постає життя людини (те, що потрібно людині для виживання) як первинна, фундаментальна цінність. Виділяються три базові цінності об'єктивістської етики: розум, цілеспрямованість та самоповага, яким відповідають три чесноти - розумність, продуктивність та гордість. Найвищою моральною метою А. Ренд називає принцип "жити заради себе", при цьому не приносячи себе в жертву іншим та не роблячи інших жертвами. Усю етику А. Ренд вибудовує на принципі раціональності (розумі), вона повинна вести людину до виживання і зростання її як людини [18].

Суспільство А. Ренд визначає як "механічну сукупність індивідів, що живуть поряд", а принцип обміну (торгівлі) як "єдиний розумний принцип для будь-яких людських взаємовідносин", адже він забезпечує справедливість та рівність у суспільстві. В основу прав людини американська письменниця та філософр ставить право на власність. Звідси етика А. Ренд - цілком капіталістична. Моральний ідеал в етиці об'єктивізму А. Ренд можна зобразити таким чином: "цілеспрямована людина з чіткою ціннісною ієрархією, вибудованою на основі власних незалежних суджень, вона не слідує загальноприйнятим традиційним правилам поведінки, а все пропускає через призму своїх моральних стандартів. Ця людина сподівається лише на власні сили й не потребує допомоги від інших людей. Вона може надати безкорисливу допомогу людям в якості акту доброї волі, керуючись своїми бажаннями" [19, с. 124]. Крізь призму етики А. Ренд феномен милосердя може виступати як суспільно корисний, однак його прояв цілком базується на бажанні індивіда. У нього немає певних внутрішніх морально-імперативних установок щодо доброчинності та турботи про благо інших.

На сучасному етапі розвитку феномен милосердя можливо корелювати з суспільно-прикладними дослідженнями неомарксизму та постмарксизму. Зокрема, з позиції постмарксизму милосердя можливо розглядати як особливу "форму" комунікації, прояв відкритості на іншого, його потреби та інтереси в межах соціуму. Указане слугує більш глибокій інтеграції індивідів, а також включеності індивіда в соціальне та природне середовища його пізнання та діяльності. Утвердження феномену милосердя в суспільстві може слугувати підставою для активної участі індивідів у самоорганізаційному самоврядуванні, формувати громадянські асоціації та активно впливати й забезпечувати інтереси суспільства (деліберативний та субсидіарний постмарксизм).

\section{Висновки}

Таким чином, ідейно-концептологічний аналіз соціально-фрілософського підходу до суспільних аспектів милосердя крізь призму західної фрілософської думки (еволюціонізм, гедонізм, утилітаризм, лібералізм) дозволив визначити, що на сьогодні милосердя в контексті суспільної практики отримує прагматичне спрямування, що пов'язується з такими факторами як користь, взаємна допомога. Ідеали самопожертви та альтруїз- 
му знаходять своє втілення в контексті прагнень індивіда, проте вже не є "суспільним" етичним імперативом. Усе це ставить милосердя як потужний інтегративний фрактор суспільства в достатньо хитке становище. Деякою мірою вказана ситуація отримує "реабілітацію" завдяки сучасним соціально-фрілософським дослідженням неомарксизму та постмарксизму, де милосердя слід розглядати підставою для активної співучасті суб'єкта та об'єкта (оточуючого суб'єкт середовища), фрактором формування громадянських асоціацій для здійснення суспільних перетворень.

\section{ЛITЕРАТУРА}

1. Bennett C. The Limits of Mercy. Ratio. 2004. Vol. 17. Issue 1. P. 1-11. DOI: 10.1111/j.1467-9329.2004.00232.x.

2. Meyer L. R. The Justice of Mercy. Ann Arbor: The University of Michigan Press, 2010. 264 p. DOI: 10.3998/mpub.328658.

3. Murphy J. G., Hampton J. Forgiveness and Mercy. Cambridge: Cambridge University Press, 1988. 194 p. DOI: 10.1017/ cbo9780511625121.

4. Kesselring K. J. Mercy and Authority in the Tudor State. Cambridge: Cambridge University Press, 2003. 242 p. DOI: 10.1017/ cbo9780511495854

5. Апресян Р. Г. Идея морали и базовые нормативно-этические программы. Москва, 1995. 353 с.

6. Спенсер Г. Синтетическая философрия. Київ: Ника-Центр, 1997. $512 \mathrm{c}$.

7. Эфроимсон В. П. Генетика этики и эстетики. СанктПетербург: Талисман, 1995. 288 с.

8. Логунова Е. Г. К вопросу о двух концепциях феномена милосердия. Дискуссия. 2012. № 3. С. 21-24.

9. Кропоткин П. А., Федоров А. Ю. (авт. предисл.); Гольд- смит М. И. (вступ. ст.); Рублёв Д. И. (прилож). Взаимная помощь среди животных и людей как двигатель прогресса. Москва: Книжный дом «Либроком», 2011

10. Сушенцова М. С. Утилитаризм И. Бентама и Дж. С. Милля: от добродетели к рациональности. Вестник СПбГУ. Экономика. 2017. Т. 33. Вып. 1. С. 17-35.

11. Серебрянский Д. С. Классический утилитаризм: основные теоретические проблемы. Этическая мысль. 2011. Вып.11. С.90-104.

12. Гайденко П. П. Нравственная природа человека в европейской традиции XIX-XX вв. Этическая мысль. М., 2000. C. $88-106$

13. Бурмистров С. Л. Антропология американского прагматизма. Человек. 2011. № 4. С. 104-115.

14. Яркова Е. Н. Утилитаризм как нравственное основание модернизации культуры и общества (на материале западной этико-фрилософрской традиции). Европа. 2004. № 4. C. $159-180$.

15. Никифоров А. Л. Индивид либерализма и его мораль. Личность. Культура. Общество. 2016. Т. 18. Вып. 1-2. С. 161177.

16. Денисов А. А. Принципы моральной регуляции общества в либеральной и традиционной этике. Омский научный вестник. 2006. № 2. С.35-41.

17. Виссенбург М. Либерализм и природа. Политическая наука. 2010. № 2. С. 88-108.

18. Рэнд А. Объективистская этика. Апология капитализмa URL: http://www.urantia-s.com/library/rand/apologiya_kapitalizma/ full (дата звернення 12.01.2018).

19. Куреных К. А. Трактовка рационального эгоизма в этике А. Рэнд. Социум и власть. 2017. № 4. С. 122-126. DOI: 10.22394/1996-0522-2017-4-122-126.

\section{Ходаныч Юрий,}

преподаватель кафедры философии,

Ужгородский начиональный университет, г. Ужгород

\section{СРАВНИТЕЛЬНЫЙ ИДЕЙНО-КОНЦЕПТОЛОГИЧЕСКИЙ АНАЛИЗ СОЦИАЛЬНО-ФИЛОСОФСКОГО ПОДХОДА К ОБЩЕСТВЕННЫМ АСПЕКТАМ МИЛОСЕРДИЯ}

Статья посвящена сравнительному идейно-концептологическому анализу социально-философского подхода к общественным аспектам милосердия. Феномен милосердия исследуется автором через призму различных западных социально-этических учений (эволюционизм, утилитаризм, гедонизм, либерализм, неомарксизм и постмарксизм). В разрезе эволюционизма милосердие получает значение альтруизма. Особое внимание уделяется концепции взаимопомощи П. Кропоткина. В утилитаризме милосердие рассматривается сквозь призму индивидуальной и общественной пользы. В свою очередь, в контексте либерализма милосердие теряет свою общественную ценность, ведь в центре внимания стоит свободная личность с собственным моральным выбором. Автор анализирует отдельным образом концепцию разумного эгоизма А. Рэнд. Сквозь призму общественно-прикладных исследований неомарксизма и постмарксизма милосердие является фактором активности субъекта в окружающей его среде и дальнейшего влияния на развитие общества.

Ключевые слова: милосердие; эволюционизм; прагматизм; утилитаризм; закон взаимной помощи; либерализм.

Khodanych Yuriy, lecturer of the Department of philosophy, Uzhgorod National University, Uzhgorod

\section{COMPARATIVE IDEAL-CONCEPTOLOGICAL ANALYSIS OF SOCIAL-PHILOSOPHICAL APPROACH TO SOCIAL ASPECTS OF MERCY}

The article is devoted to the comparative ideological and conceptual analysis of the socio-philosophical approach to the social aspects of mercy. The phenomenon of mercy is studied by the author through the prism of a variety of Western social and ethical teachings (evolutionism, utilitarianism, hedonism, liberalism, neo-Marxism and post- 
Marxism). In the context of evolutionism, mercy receives the significance of altruism. Particular attention is paid to the concept of mutual assistance by $P$. Kropotkin. In utilitarianism mercy is viewed through the prism of individual and social benefit. In turn, in the context of liberalism, mercy loses its social value, since the focus is on a free personality with its own moral choices. The author analyzes the concept of rational selfishness in a separate way by A. Rand. Through the prism of social and applied research of neo-Marxism and post-Marxism mercy appears as a factor in the subject's activity in relation to its environment and its subsequent influence on the development of society. The ideological and conceptual analysis of the socio-philosophical approach to the social aspects of mercy through the prism of Western philosophical thought (evolutionism, hedonism, utilitarianism, liberalism) allowed us to determine that today mercy in the context of social practice receives a pragmatic orientation, which is associated with such factors as benefits, mutual assistance. In turn, the ideals of self-sacrifice and altruism are embodied in the context of the aspirations of the individual, but are no longer a "social" ethical imperative. All this puts mercy as a powerful integrative factor of society in a rather shaky situation. To a certain extent, the situation is "rehabilitated" due to modern socio-philosophical research of neo-Marxism and post-Marxism, where mercy should be considered as the basis for active complicity of the subject and object, the factor of the formation of civil associations for the implementation of social transformations.

Key words: mercy; evolutionism; pragmatism; utilitarianism; law of mutual assistance; liberalism.

\section{REFERENCES}

1. Bennett, C., 2004. The Limits of Mercy. Ratio. Vol. 17, Issue 1, pp. 1-11 DOI: 10.1111/j.1467-9329.2004.00232.x.

2. Meyer, L.R., 2010. The Justice of Mercy. Ann Arbor: The University of Michigan Press, 264 p. DOI: 10.3998/mpub.328658.

3. Murphy, J.G., Hampton, J., 1988. Forgiveness and Mercy. Cambridge: Cambridge University Press, 194 p. DOI: $10.1017 /$ cbo9780511625121.

4. Kesselring, K.J., 2003. Mercy and Authority in the Tudor State. Cambridge: Cambridge University Press, 242 p. DOI: $10.1017 /$ cbo9780511495854.

5. Apresian, R.G., 1995. The idea of morality and basic normative and ethical programs. Moscow, 353 p. (rus)

6. Spencer, H., 1997. Synthetic philosophy. Kyiv: Nika-Centr, 512 p. (rus)

7. Efroimson, V.P., 1995. Genetics of Ethics and Esthetics. St. Peterburg: Talisman, 288 p. (rus)

8. Logunova, E.H., 2012. To the question of two concepts of the phenomenon of mercy. Discussion, 3, pp. 21-24. (rus)

9. Kropotkin, P.A., 2011. Mutual assistance among animals and humans as the engine of progress. Moscow: Librokom. (rus)

10. Sushentsova, M.S., 2017. Utilitarianism of I. Bentham and J.S. Mill: from virtue to rationality. Bulletin of St. Petersburg State University. Economy, Vol. 33, Issue 1, pp. 17-35. (rus)

11. Serebrianskiy, D.S., 2011. Classical utilitarianism: the main theoretical problems. Ethical thought, Issue 11, pp. 90-104. (rus)

12. Gaydenko, P.P., 2000. The moral nature of man in the European tradition of the XIX-XX centuries. Ethical thought, pp. 88-106. (rus)

13. Burmistrov, S.L., 2011. Anthropology of American pragmatism. Human, 4, pp. 104-115. (rus)

14. Yarkova, E.N., 2004. Utilitarianism as a moral basis for the modernization of culture and society (based on the Western ethical and philosophical tradition). Europe, 4, pp. 159-180. (rus)

15. Nikiforov, A.L., 2016. The Individual of Liberalism and its Moral. Personality. Culture. Society, V. 18, Issue 1-2, pp. 161-177. (rus)

16. Denisov, A.A., 2006. Principles of moral regulation of society in liberal and traditional ethics. Omsk scientific Bulletin, 2, pp. 3541. (rus)

17. Vissenburg, M., 2010. Liberalism and nature. Political science, 2, pp. 88-108. (rus)

18. Rand, A. Objective Ethics. In The Apology of Capitalism. Available at: http://www.urantia-s.com/library/rand/apologiya_kapitalizma/ full.

19. Kurenykh, K.A., 2017. The treatment of rational egoism in ethics of A. Rand. Social life and power, 4, pp. 122-126. DOI: 10.22394/ 1996-0522-2017-4-122-126.

(С) Ходанич Юрій

Надійшла до редакції 15.02.2018 